\title{
100 éve született Csömör Sándor szülészprofesszor
}

Csömör Sándor (1919-2007) Dunavecsén, egy vadasi tanyán született 1919. december 14-én. Szülei földmüvesek voltak. Tőlük tanulta meg a föld, az élet, a munka és az ember tiszteletét. Apját korán elveszítette, édesanyja 83 évig élt (1. ábra).

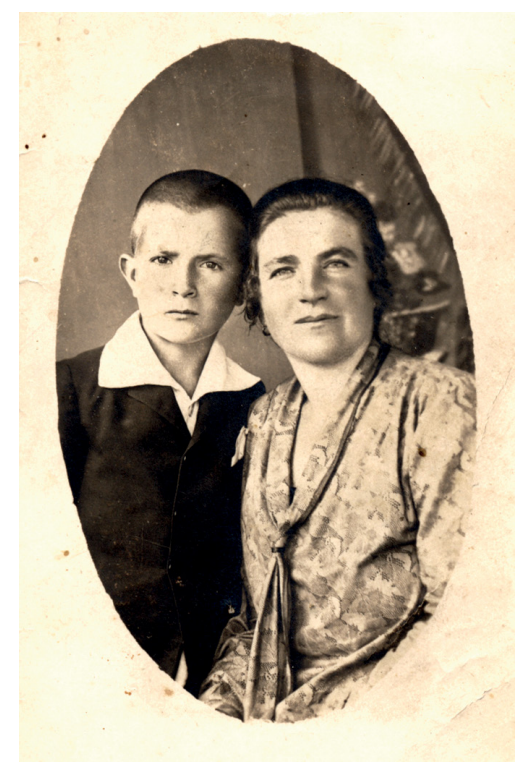

1. ábra

| Csömör Sándor édesanyjával Dunavecsén

Az elemi iskolát szülőfalujában, a középiskolát Kunszentmiklóson, a Baksay Sándor Református Gimnáziumban végezte, ahol kitüntetéssel érettségizett. Az önképzőkör elnöke és a Soli Deo Gloria református diákegyesület tagja volt. Jó tanulmányi eredményei miatt tandíjmentességet élvezett, ennek ellenére szüleinek nagy erőfeszítésébe került taníttatása.

Egyetemi tanulmányait 1938-ban a Pázmány Péter Tudományegyetem Orvosi Karán kezdte és 1944-ben fejezte be. 1944. szeptember 1-jén lépett be orvosként az I. Sz. Szülészeti és Nőgyógyászati Klinikára, ahol Frigyesi József professzor felterjesztése alapján díjtalan gyakornokként kezdte klinikai pályafutását. Horn Béla volt a tanítómestere, akiről mindig szívből jövő hálával emlékezett meg. Irányítása alatt 1958-tól adjunktusi, 1963-tól egyetemi docensi munkakörben dolgozott. Szülészetnőgyógyászatból, sugaras eljárásokból és klinikai onkológiából szerzett szakképesítést. Az elsők egyike volt, aki e három szakképzettséggel rendelkezett hazánkban. Pá- lyafutása alatt közel tízezer, rosszindulatú daganatban szenvedő nóbeteget gyógyított, vagy irányította kezelésüket. E témakörből írta tudományos értekezését is. 1972 júliusában lett egyetemi tanár és az I. Sz. Szülészeti és Nőgyógyászati Klinika igazgatója, s ezt a feladatot 1990-ig látta el. 1987. szeptember 26-án nagy alázattal rendezte meg a Női Klinika alapításának 175. évfordulóját. (A 200. évforduló megünnepléséről 2012-ben az akkori igazgató megfeledkezett.) Klinikaigazgatóként, a Magyar Nőorvos Társaság elnökeként és rektorhelyettesként jutott a csúcsra.

Hazánkban elsóként valósította meg az egységes perinatalis ellátási rendszert, azaz a szülészeti és neonatológiai ellátás egy intézeten belüli, koncepcionálisan egységes biztosítását, ami a neonatalis intenzív centrumok kialakításának alapját képezte. A klinikán 1971-re a kezdeti próbálkozásokból létrejött a valódi intenzív szülésészlelés. Az intézetben kifejlesztett direkt magzati elektróda, valamint az ágy melletti monitorok segítségével magas színvonalra emelte az intrauterin magzati diagnosztikát. Elsőként helyezett kiemelt hangsúlyt a szülészeti és nőgyógyászati pszichoszomatikai szemléletre és a fizioterápiára. Az 1970-es évek vége felé, alig egy évvel a világon elsőként szervezeten kívül fogant magzat születését követően fogalmazódott meg benne az igény és a szándék, hogy a meddőség kezelésének e speciális módszere a klinikán is bevezetésre kerüljön. Már nyugállományban volt, amikor álma beteljesedett: 1995-ben megszületett a klinika szülőszobáján a klinikán in vitro fogant első lombikbébi.

A medikusoktatás is a szívügyei közé tartozott; az 1970-es években a klinikán készített színes oktatófilmek alkalmazása az előadások illusztrálására, majd az 1980-as években a medikusok egyhetes bentlakásos gyakorlatának kimunkálása és bevezetése is a nevéhez füződik. Vezetése alatt a klinikán két munkatársa akadémiai doktori címet szerzett, tizenhét munkatársa - köztük két külföldi kolléga - kandidátusi fokozatot nyert, hat munkatársa egyetemi tanár, számos pedig osztályvezető foóorvos lett.

1990-ben történt nyugállományba vonulása után a klinika szaktanácsadója, az Egészségügyi Tudományos Tanács (ETT) Igazságügyi Bizottságának referense, a budapesti Igazságügyi Orvosszakértői Intézet szülésznőgyógyász igazságügyi szakértője volt. Szavazás eredményeként az elsők között kapta meg a Professor Emeritus címet 1996. július 1 -jén. Boldogan járt be nyugdíjas évei alatt is a klinikára betegeihez, volt tanítványaihoz. 


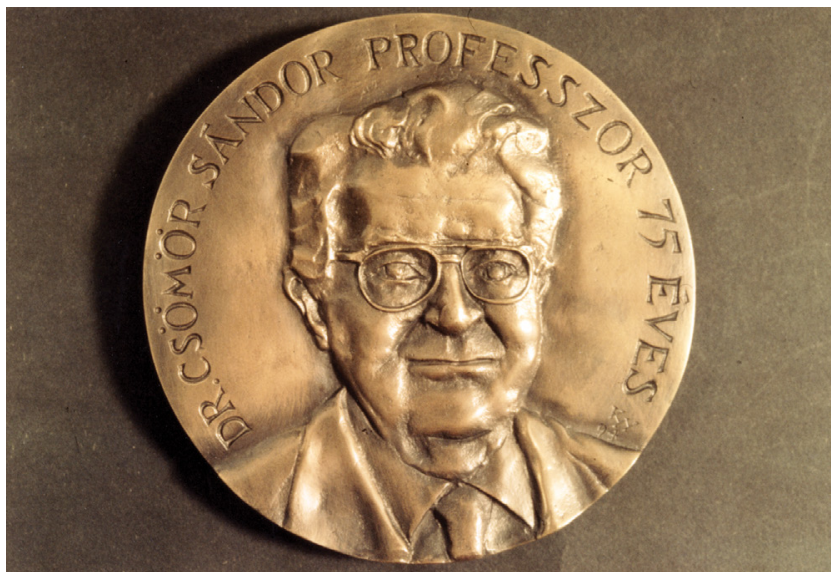

2. ábra

Csömör Sándor professzor 75. születésnapja tiszteletére a klinika kollektívája emlékérmet készíttetett (1994. december 14.)

Mindig nagy megbecsülés és szeretet vette körül, nyugdíjba vonulása után még évekig operált. A múló évek terhei, betegség, a szeretett feleségének elvesztése feletti gyász megpróbáltatásai ellenére is hüséggel és örömmel vett részt a klinika szinte minden fontos rendezvényén, ahol szeretettel várt és köszöntött vendég volt.

Példaértékü a pályafutása a magyar XX. századra jellemző történelmi elemekkel, hiszen 1919-ben, az I. világháború befejeződése utáni, Magyarország számára sorspróbáló időben született. Tehetsége, szorgalma révén vált első generációs értelmiségivé, 1944-ben, a II. világháború világégése közepette fejezte be orvosi tanulmányait, és lett a katonazubbonyt levetve pályakezdő doktor. Az ország szívéből, a Duna-Tisza közéről jött. Keménységében, egyenességében a szülőföld közösségének etikája, a hangsúlyos Petőfi-kultusz, a tiszta és szigorú református családi, ifjúsági indíttatás biztosan mind meghatározó volt. Igazság- és realitásérzéke, két lábbal a földön állása büszkén vállalt paraszti származásban, neveltetésben gyökeredző vonás, ugyanakkor a jövőbe tekintő, gyakran ösztönösen „ráérző” remek meglátásainak készségét is bizonnyal a mindig feljebb és mindig előbbre törekvő gazdaősöktől örökölte. Munkatársait szóban és tettekben a mindenkori személyes példamutatásával is arra tanította, nevelte, hogy mindig a beteg a legfontosabb. Szigorú, de igazságos és következetes volt. A leglényegesebb erénynek a tisztességet tartotta. Szállóigévé vált a mondata: „Apám, milyen ember vagy? Aztán nem baj az se, ha zseni.” Arra a kérdésre, hogy Sándor bátyám, mi a titka a hosszú életnek, azt válaszolta: „Csak a légzést soha nem szabad abbahagyni!” A végsőkig való küzdésre és kitartásra buzdító mondata szintén szállóigévé vált a klinikán.

1990-ben, a rendszerváltást követően adta át a klinikát utódjának a megújításba és a XXI. századba vetett hitével és reményével. Csömör professzorral mint tanszéki elődömmel őszinte, tiszta kapcsolatban voltunk, szerettük és tiszteltük egymást. Nagyon sokat jelentett állandó

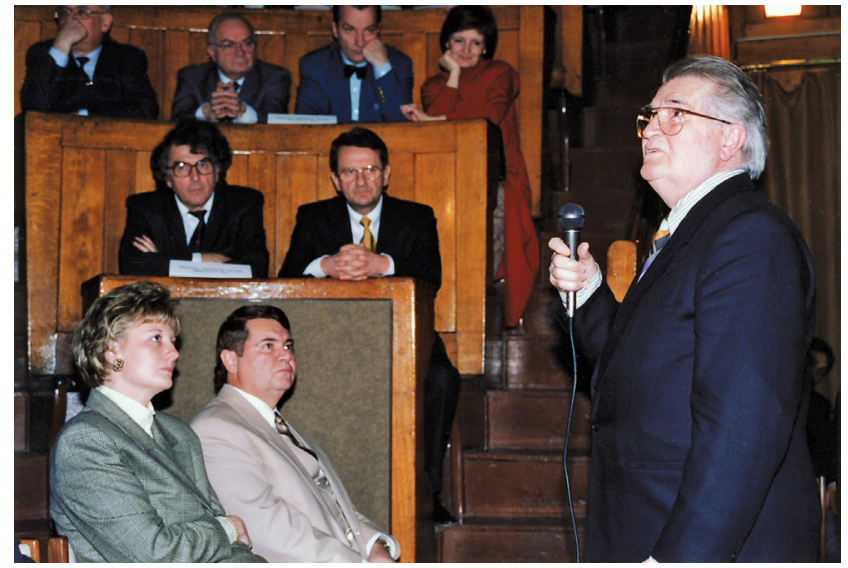

3. ábra

Csömör Sándor professzor megköszöni a 80. születésnapján kapott jókívánságokat, és megosztja a hallgatósággal néhány múlt beli emlékét. (A Baross Utcai Szülészeti Esték 34. rendezvénye, 1999. december 9.)

buzdítása, lépéseim visszaigazolása, őszintén velünk együtt örült a klinika megújulásának. Amikor már nem tudott bejönni a klinikára, Sándor-napokon én látogattam meg otthonukban. Éreztem, hogy ragaszkodásomat mindig őszintének tekintette; nem tudnék ma sem elképzelni példásabb kapcsolatot tanszéki előd és utód között, és ezt ő is többször hangsúlyozta. Ebből sem lett hagyomány a klinikán.

1994. december 15-én, tudományos ülés keretében köszöntöttük 75., 1999. december 9-én, a 34. Baross Utcai Szülészeti Estéken a 80. születésnapján. A 75. születésnapjára a klinika kollektívája emlékérmet készíttetett (2. és 3. ábra). A Semmelweis Egyetem II. Sz. Szülészeti és Nőgyógyászati Klinikájának igazgatójával, Paulin Ferenc professzorral 2001-ben Semmelweis-Tauffer Emlékdíjat alapítottunk a magyar szülészet legnagyobbjainak évenkénti díjazására. Az első Emlékülést Tauffer Vilmos születésének 150. évfordulójának évében, 2001. október 10-én tartottuk. Az első két Emlékdíjat Zoltán Imre professzornak, a társklinika nyugalmazott igazgatójának, és Csömör Sándor professzornak, az általam

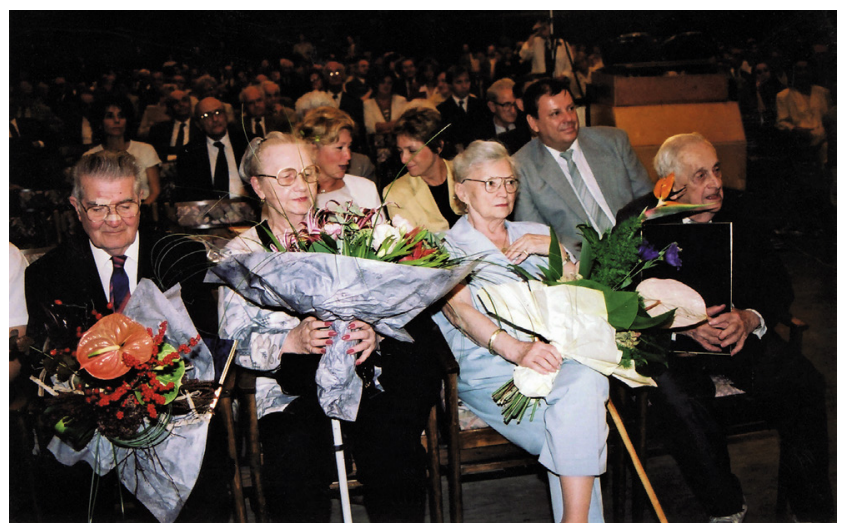

4. ábra $\mid$ Az ünnepeltek feleségeikkel a Semmelweis-Tauffer Emlékdíj át vétele után (2001. október 10.) (Balról jobbra Csömör Sándor professzor és felesége, Zoltán Imre felesége és Zoltán Imre professzor) 


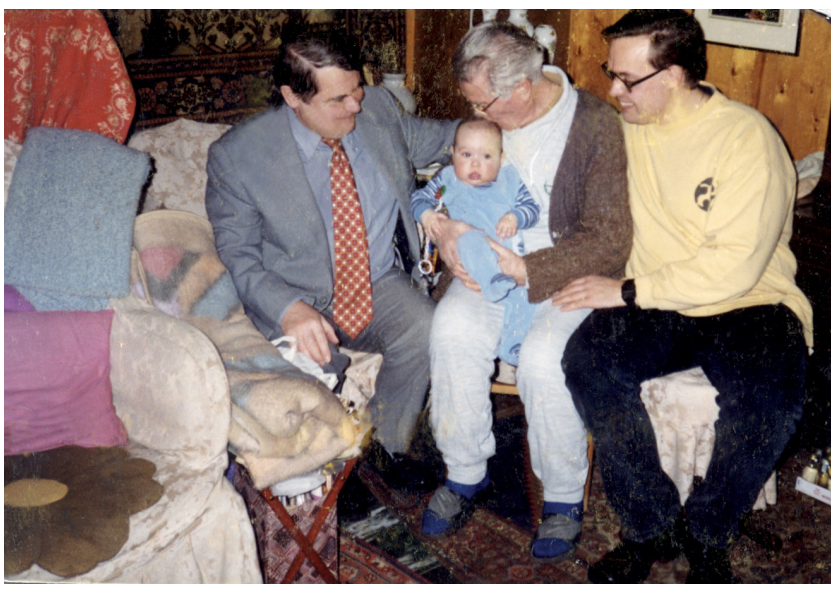

5. ábra

| A négy Csömör Sándor „találkozója” 2000 márciusában Sán-

vezetett klinika nyugalmazott igazgatójának adtuk (4. ábra). A díj átvételekor Csömör professzor a következő szavakkal köszönte meg a megbecsülését: „Életemben több mint húsz kitüntetést kaptam, de túlzás nélkül állíthatom, hogy ez a mostani, a két legnagyobb magyar szülész-nőgyógyász nevével ellátott elismerés a legmeghatóbb számomra. Semmelweis Ignác tanszéki utódaként e kitüntetést megkapni egész küzdelmes életem visszaigazolása. Ha újrakezdeném, ismét az orvosi pályát és a szülészeti-nőgyógyászati hivatást választanám, ismét következetesen az emberi értékeket tisztelném, és kizárólag érdemei szerint osztályoznám az embereket, ismét a betegek szolgálatát tekinteném a legfőbb törvénynek, és ismét legjobb tudásommal, szorgalmammal és kitartá-

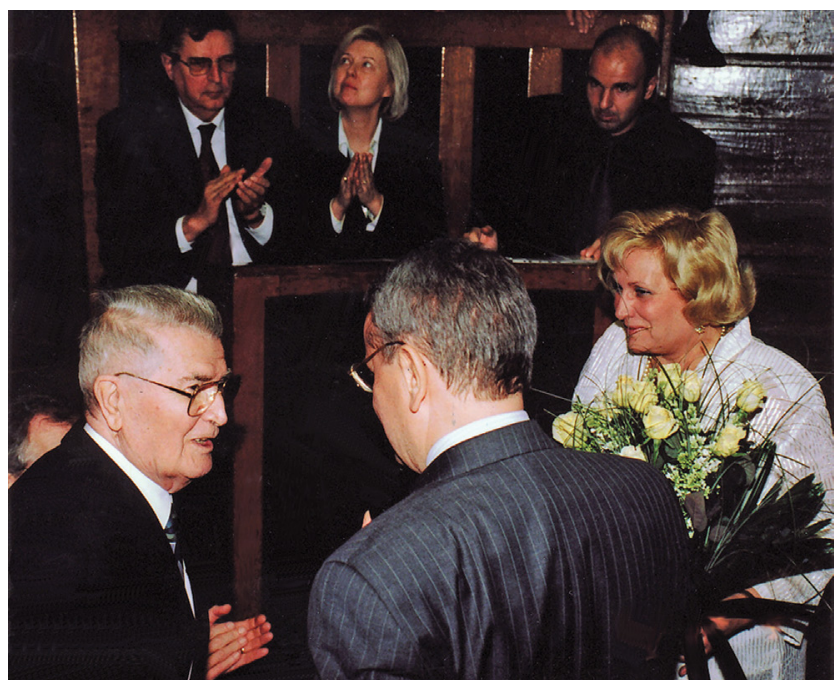

6. ábra

Csömör Sándor professzor köszöntése 85. születésnapján a Baross Utcai Szülészeti Esték 54. rendezvényén. (Budapest, 1994 december 15.) (A kép jobb oldalán Bodó Mária fómadám) sommal vállalkoznék az élet kihívásaira. Hálás vagyok a sorsnak, hogy ezt a napot megélhettem, és kívánom önöknek, hogy jelentsen a munka és a hivatás olyan örömet és boldogságot az önök számára is, mint amilyet nekem jelentett a több mint nyolc évtizedes életem során." (A Semmelweis-Tauffer-ülést és -dijazást még két alkalommal, 2003-ban és 2005-ben megismételtük, de aztán a klinikáról való távozásommal ez a hagyomány is megszünt.)

Első fia már tizenévesen az élő példaképnek tekintett Apa hivatását választotta, közvetlenül látva áldozatos napjait és éjszakáit. Szülész-nőgyógyász egyetemi docens lett belőle. Szüleivel, húgával, akiből ügyvéd lett, és a későbbi reklámszakember öccsével sokáig egyetemi szolgálati lakásban éltek, majd 1965-től kertes budai ház jelentette a családi fészket, amely elhozta a családi ünnepek és éneklő összejövetelek révén az igazi összetartozás élményét. Csömör professzor szeretett kertészkedni, a gyümölcsfák ápolásán kívül kedvencei a rózsabokrok voltak. Szerette a zenét, különösen a moll hangnemben írt szomorkás dalokat. Kedvenc énekesei Gilbert Bécaud, Charles Aznavour és Sárdy János voltak. A dunavecsei nyaralások és hétvégi kikapcsolódások biztosították a család számára a falu nyugalmának minden előnyét, a Dunapart pedig az úszó- és evezósprogramok gazdag választékát. Gyerekei hét unokával ajándékozták meg, 80 éves korában pedig dédunokája, a negyedik Csömör Sándor is megszületett (5. ábra). Gyerekei számíthattak minden élethelyzetben bölcs tanácsaira és önzetlen segítségére.

Három évvel halála előtt, 2004-ben a Baross Utcai Szülészeti Esték 54. rendezvényén ünnepeltük 85. születésnapját klinikánk tantermében, s talán ez volt az igazi búcsúzása (6. ábra). Bár ezt követően egyre kevesebbet jött be a klinikára, kevés nap volt, hogy munkánk során ne idéztük volna, ne gondoltunk volna rá, és ne aggódtunk volna egészségéért.

Csömör Sándor professzor több mint 60 termékeny évet töltött a magyar szülészet-nőgyógyászatban, keze nyoma ott van és ott is marad a szakma múködésén és az általa szívvel-lélekkel, lelkiismerettel szolgált Baross utcai klinikán. Mit tanulhattunk Tőle? A becsületes dolgos szülői példaképállítást, a tehetséget szorgalommal párosító akaraterőt, a gimnáziumi évek meghatározó szerepét, a kritikus és reális helyzetfelismerést, az új dolgokból a valóban maradandó kiválasztásának képességét, a választott hivatás szeretetét és végsőkig való szolgálatát. Csömör Sándor professzor 2007. február 21-én halt meg, és március 26-án a Fiumei Úti Sírkertben vettünk tőle végső búcsút.

Papp Zoltán dr.

"Potest ex casa magnus vir exire." (Seneca) (Kunyhóból is származhat nagy férfi.) 